\title{
PENGEMBANGAN SUMBER DAYA MANUSIA \\ MELALUI ANALISIS TRANSPARANSI REKRUTMEN \\ CALON PEGAWAI NEGERI SIPIL \\ PADA BADAN KEPEGAWAIAN DAN PENGEMBANGAN SUMBER DAYA MANUSIA KABUPATEN SUMEDANG PROVINSI JAWA BARAT
}

Oleh

\section{Didi Supriadi}

Institut Pemerintahan Dalam Negeri

supriadidi2323@gmail.com

\begin{abstract}
7 This study aims to study, analyze and describe the application of transparency of CPNS 1 recruitment at BKPSDM Sumedang Regency, West Java Province. Data obtained through documentation and interviews with informants relating to research, namely: Head of BKPSDM, Secretary of BKPSDM, Head of Procurement and Staff Departments, and the Community, as well as library research.

The research method that I use is descriptive research method with a qualitative approach. The results showed that the application of the CPNS recruitment process at the BKPSDM Sumedang District was transparent. Inhibiting factors in this study include, Announcement from the National Committee, Honorary Workers Education, and Community Participation.
\end{abstract}

Keywords: transparency, recruitment

\section{Abstrak}

Denelitian ini bertujuan untuk mengkaji, menganalisis dan mendeskripsikan penerapan transparansi rekrutmen CPNS pada BKPSDM Kabupaten Sumedang Provinsi Jawa Barat. Data diperoleh melalui dokumentasi dan wawancara dengan informan yang berkaitan dengan penelitian, yaitu: Kepala BKPSDM, Sekretaris BKPSDM, Kepala Bidang Pengadaan dan Kepangkatan Pegawai, dan Masyarakat, serta pencarian kepustakaan.

Metode penelitian yang digunakan, yaitu dengan metode penelitian deskriptif dengan pendekatan kualitatif. Hasil penelitian menunjukkan bahwa penerapan proses rekrutmen CPNS pada BKPSDM Kabupaten Sumedang sudah transparan. Faktor yang menghambat dalam penelitian ini antara lain pengumuman dari Panselnas, pendidikan tenaga honorer, dan partisipasi masyarakat.

Kata kunci: transparansi, rekrutmen

\section{PENDAHULUAN}

Cumber daya manusia merupakan pemerintahan. Pemerintahan yang baik adalah pemerintahan yang mampu memberikan pelayanan terbaik untuk masyarakat baik dari segi kecepatan maupun ketepatan dalam pelayanan publik dan ketepatan sasaran bagi 
masyarakat yang membutuhkan. Kebutuhan masyarakat terhadap kepentingan pribadi dan umum dapat tercapai dengan maksimal. Karena itu, perlu diperhatikan kualitas sumber daya manusia yang berfungsi sebagai tenaga penggerak dalam melaksanakan tugas dan tanggung jawab untuk mencapai keberhasilan dalam menyejahterakan masyarakatnya. Sumber daya manusia (SDM) sering disebut sebagai human resource, tenaga atau kekuatan manusia (energi atau power). Sumber daya juga disebut sumber tenaga, kemampuan, kekuatan, keahlian yang dimiliki oleh manusia. Seiring dengan perkembangan teknologi dan perubahan-perubahan dunia yang semakin hari semakin kompleks, menuntut seseorang untuk selalu meningkatkan kemampuan yang dimilikinya sesuai dengan kapasitas perubahan tersebut. Pada dasarnya manusia memiliki potensi dasar dan kemampuan yang idealnya akan terus menerus berkembang apabila diasah secara kontinyu dan berkelanjutan.

Kenyataan yang terjadi adalah proses pelaksanaan rekrutmen pegawai negeri sipil (PNS) sering kali menjadi sorotan di masyarakat, permasalahan pro-kontra yang terjadi di masyarakat disebabkan lemahnya mekanisme penyelenggaraan rekrutmen sehingga menyebabkan munculnya ketidakpuasan di masyarakat. Sejumlah permasalahan yang muncul di masyarakat terkait dengan rekrutmen adalah ketidaktransparannya proses penyelenggaraan rekrutmen, dan masih adanya praktik korupsi, kolusi, dan nepotisme (KKN). contoh ketidakpuasan masyarakat terhadap kinerja pemerintah khususnya pemerintah daerah adalah dalam proses rekrutmen pegawai. Sebagaimana yang diungkapkan Simanjuntak (2001:27), bahwa proses rekrutmen pegawai yang dilaksanakanoleh pemerintahmasih terdapat praktik KKN. Hal tersebut terjadi akibat adanya penyalahgunaan kewenangan (abuse of power) dan tidak adanya transparansi di dalam pelaksanaan sistem rekrutmen tersebut. Hal ini membuat citra pemerintah semakin jelek di mata masyarakat luas, akibatnya tingkat kepercayaan masyarakat kepada pemerintah semakin berkurang.

Penyelenggaraan manajemen kepegawaian di daerah khususnya dalam upaya rekrutmen PNS dewasa ini, masih dijumpai banyak permasalahan. Rendahnya tingkat kepercayaan masyarakat terhadap aparatur birokrasi merupakan salah satu indikasi kuat bahwa sistem rekrutmen yang selama ini diterapkan dinilai kurang baik, terutama dari segi pelayanan publik (public services). Dalam Peraturan Pemerintah No. 97 Tahun 2000 tentang Formasi Pegawai Negeri Sipil Pasal 3 ayat (2) menyebutkan bahwa "Formasi Pegawai Negeri Sipil Daerah untuk masingmasing satuan organisasi Pemerintah Daerah setiap tahun anggaran ditetapkan oleh Kepala Daerah". Namun di dalam Peraturan Pemerintah tersebut tidak dirinci secara jelas bagaimana prosedur penetapan formasi pegawai negeri sipil, sehingga tidak dapat diketahui dengan jelas apakah jurusanjurusan yang terdapat pada formasi tersebut betul-betul menjadi kebutuhan Pemerintah Daerah. Sebagaimana disampaikan oleh Wigati (2007), bahwa transparansi ataupun keterbukaan dalam proses rekrutmen PNS masih belum sepenuhnya terwujud.

Permasalahan yang muncul pada rekrutmen biasanya terkait dengan unsur kolusi, yaitu adanya bentuk kerja sama yang secara ilegal dilakukan oleh oknumoknum tertentu untuk mendapatkan keuntungan bagi mereka. Wahyu (2008) dalam hasil penelitiannya menyebutkan proses rekrutmen PNS di Jawa Barat mendapat pengaruh yang cukup signifikan dari politisi. Salah satu akibatnya adalah sering kali dalam proses rekrutmen terdapat oknum yang belum memiliki kompetensi pada bidang tersebut harus dinyatakan lulus dan diangkat menjadi seorang PNS. Zebua 
(2010) menyampaikan terdapat beberapa kendala dalam proses rekrutmen antara lain kurangnya penyampaian informasi ataupun permasalahan dana/anggaran pelaksanaan. Kurangnya transparansi yang diterapkan oleh pemerintah dalam seleksi penerimaan PNS menimbulkan persepsi negatif di kalangan masyarakat yang mengindikasikan adanya penyalahgunaan wewenang sehinga menimbulkan praktik KKN di dalam proses rekrutmen PNS.

Penandatanganan Surat Keputusan Bersama (SKB) Tiga Menteri, yaitu Menteri Keuangan, Menteri Pendayagunaan Aparatur Negara dan Reformasi Birokrasi, dan Menteri Dalam Negeri terkait moratorium atau penghentian sementara perekrutan PNS pada 24 Agustus 2011, sehingga pada 2012 tidak dilaksanakan penerimaan CPNS di Kabupaten Sumedang. Pada 2013 dan 2014 sampai dengan 2018 Kabupaten Sumedang juga tidak mendapatkan formasi untuk penerimaan pegawai, dikarenakan belanja pegawai di Kabupaten Sumedang cukup tinggi mencapai $67,37 \%$ dari total anggaran pendapatan dan belanja daerah (APBD) atau lebih tinggi dari belanja publik. Terdapat pengecualian terhadap penerimaan CPNS dari para tenaga honorer kategori II dan umum dengan latar belakang pendidikan formasi pada 2014-2018, di mana BKPSDM Kabupaten Sumedang juga tetap melaksanakan penerimaan CPNS bagi tenaga honorer K2 dan untuk penerimaan CPNS umum melaksanakan penerimaan baru pada 2019. Sesuai dengan pengumuman kelulusan peserta seleksi CPNS 2019 yang dikeluarkan oleh Kementerian Pendayagunaan Aparatur Negara dan Reformasi Birokrasi Nomor B/789/M.PAN/2/2017 terdapat 970 orang yang dinyatakan lulus dari peserta yang berjumlah 3.314 orang. Sebelum menyampaikan berkas usulan permintaan nomor induk pegawai (NIP) ke badan kepegawaian negara (BKN), setiap instansi wajib melakukan verifikasi ulang kebenaran dokumen dari masing-masing tenaga honorer kategori II dan umum. Sejumlah 970 orang yang dinyatakan lulus CPNS bagi tenaga honorer dan umum, terdapat 357 honorer yang dinyatakan belum memenuhi syarat administratif yang ditentukan, sehingga tidak dapat diangkat atau dibatalkan menjadi CPNS, sedangkan yang dinyatakan lulus 543 orang dari honorer K2 dan umum sesuai latar belakang pendidikan.

\section{TINJAUAN PUSTAKA}

\section{Transparansi}

Transparansi merupakan salah satu prinsip good corporate governance, di mana good corporate governance dapat diartikan sebagai kepemerintahan yang baik atau penyelenggaraan pemerintahan yang bersih dan efektif, sesuai dengan peraturan dan ketentuan yang berlaku. Menurut Pieris dan Nizam (2008: 132), prinsip-prinsip good corporate governance adalah sebagai berikut.

1. Prinsip Partisipasi

Prinsip partisipasi menekankan keterlibatan dan peran serta semua pemangku kepentingan dalam proses pengambilan keputusan dan perumusan kebijakan, pelaksanaan kebijakan dan program kebijakan, serta pengawasannya. Partisipasi dapat diwujudkan secara langsung melalui perwakilan.

2. Prinsip Hukum dan Aturan

Prinsip hukum dan aturan berarti bahwa semua kebijakan pemerintahan harus dituangkan ke dalam peraturan perundang-undangan sesuai dengan tingkat urgensinya, yaitu undangundang, peraturan pemerintah, keputusan presiden, keputusan menteri, dan peraturan daerah. Pelaksanaan tugas dan pelayanan setiap aparat dan lembaga pemerintah harus sesuai dengan atau berdasarkan peraturan perundang-undangan tersebut. Hukum 
dan aturan harus mampu melindungi hak azasi manusia terutama hak-hak kelompok minoritas.

3. Prinsip Transparansi

Prinsip transparansi berarti bahwa semua penyelenggara pemerintahan harus terbuka kepada masyarakat umum, baik dalam pengambilan keputusan dan perumusan kebijakan maupun dalam pelaksanaan dan pengawasannya, terutama setiap orang yang berkaitan dengan suatu keputusan perlu memiliki akses untuk memperoleh informasi yang dibutuhkan.

4. Prinsip Responsivitas

Prinsip responsivitas berarti bahwa aparatur pemerintah harus cepat bertindak atau merespons harapan, tuntutan, keluhan dan penderitaan masyarakat yang dinyatakan secara langsung atau tidak langsung.

\section{Prinsip Orientasi Konsensus}

Prinsip orientasi konsensus merupakan kelengkapan dari prinsip partisipasi, yaitu pengambilan keputusan secara musyawarah untuk mufakat dengan melibatkan sebanyak mungkin anggota serta memperhatikan kepentingan semua unsur atau stakeholders.

6. Prinsip Keadilan dan Kewajaran

Prinsip keadilan dan kewajaran berarti distribusi tugas dan kewenangan, kewajiban dan hak harus dilakukan secara adil (equity) dan wajar (fair) sesuai dengan peraturan perundangundangan dan ketentuan yang berlaku. Setiap anggota harus dapat merasakan diperlakukan sama dengan yang lain, memperoleh imbalan proporsional terhadap kontribusinya, serta memperoleh kesempatan untuk berkembang dan meningkatkan kesejahteraannya.

\section{Prinsip Efisiensi dan Efektivitas}

Prinsip efisiensi dan efektivitas berarti bahwa dalam setiap pelaksanaan tugas harus mengupayakan penggunaan sehemat mungkin sumber-sumber yang terbatas dan mencapai hasil seoptimal mungkin, sasaran atau tujuan organisasi. Penggunaan sumber-sumber harus tetap mengacu pada kelestarian lingkungan.

8. Prinsip Akuntabilitas

Prinsipakuntabilitas berartibahwasetiap pelaksanaan tugas, penggunaan sumbersumber, serta penggunaan wewenang harus dapat dipertanggungjawabkan, transparan, dan terbuka untuk diaudit atau diperiksa baik oleh pihak yang berkepentingan maupun melalui lembaga yang independen.

9. Prinsip Visi Strategis

Prinsip visi strategis berarti bahwa strategi pelaksanaan tugas masingmasing harus disusun dan mengacu pada visi dan misi organisasi.

Transparansi adalah prinsip yang menjamin akses atau kebebasan setiap orang untuk memperoleh informasi tentang penyelenggaraan pemerintahan, yakni informasi tentang kebijakan, proses pembuatan dan pelaksanaannya, serta hasilhasil yang dicapai (Buku Pedoman Penguatan Pengaman Program Pembangunan Daerah, Badan Perencanaan Pembangunan Nasional dan Departemen Dalam Negeri, 2002:18).

Selanjutnya, Widodo (2001:28) mengungkapkan bahwa transparansi lebih mengarah kepada kejelasan mekanisme formulasi dan implementasi kebijakan, program dan proyek yang dibuat dan dilaksanakan pemerintah. Rakyat dapat mengetahui secara jelas dan tanpa ada yang ditutupitentang proses perumusan kebijakan publik dan implementasinya. Dengan kata lain segala kebijakan dan implementasi kebijakan harus selalu dilaksanakan secara terbuka dan diketahui umum. 
Menurut Loina Lalolo Krina (indikator dan alat ukur prinsip akuntabilitas, transparansi dan partisipasi dalam bappenas.go.id), transparansi adalah prinsip yang menjamin akses atau kebebasan bagi setiap orang untuk memperoleh informasi tentang penyelenggaraan pemerintahan, yakni informasi tentang kebijakan, proses pembuatan dan pelaksanaannya serta hasil-hasil yang dicapai. Transparansi yakni adanya kebijakan terbuka bagi pengawasan, sedangkan yang dimaksud dengan informasi adalah informasi mengenai setiap aspek kebijakan pemerintah yang dapat dijangkau oleh publik. Keterbukaan informasi diharapkan akan menghasilkan persaingan politik yang sehat, toleran, dan kebijakan dibuat berdasarkan pada preferensi publik. Prinsip ini memiliki dua aspek, yaitu (1) komunikasi publik oleh pemerintah, dan (2) hak masyarakat terhadap akses informasi. Keduanya akan sangat sulit dilakukan jika pemerintah tidak menangani kinerjanya dengan baik.

Lebih lanjut Loina Lalolo Krina (indikator dan alat ukur prinsip akuntabilitas, transparansi dan partisipasi dalam bappenas.go.id), menyatakan bahwa prinsip transparansi paling tidak dapat diukur melalui sejumlah indikator sebagai berikut.

1. Penyediaan informasi yang jelas tentang prosedur-prosedur, biaya-biaya dan tanggung jawab.

2. Kemudahan akses informasi.

3. Menyusun suatu mekanisme pengaduan jika ada peraturan yang dilanggar atau permintaan untuk membayar uang suap.

4. Meningkatkan arus informasi melalui kerja sama dengan media massa dan lembaga non pemerintahan.

Keterbukaan pemerintah atas berbagai aspek pelayanan publik, pada akhirnya akan membuat pemerintah menjadi bertanggung jawab kepada semua stakeholders yang berkepentingan dengan proses maupun kegiatan dalam sektor publik. Menurut Agus Dwiyanto (2008: 223), transparansi merupakan konsep yang sangat penting dan menjadi semakin penting sejalan dengan semakin kuatnya keinginan untuk mengembangkan praktik good governance. Praktik good governance mensyaratkan adanya transparansi dalam proses penyelenggaraan pemerintahan secara keseluruhan. Pemerintah dituntut untuk terbuka dan menjamin akses stakeholders terhadap berbagai informasi mengenai proses kebijakan publik, alokasi anggaran untuk pelaksanaan kebijakan, serta pemantauan dan evaluasi terhadap pelaksanaan kebijakan.

Untuk mengukur transparansi pelaksanaan suatu pelayanan, Dwiyanto (2008:236) mengungkapkan setidaknya ada tiga indikator yang dapat digunakan untuk mengukur transparansi pelayanan publik, yaitu sebagai berikut.

1. Mengukur tingkat keterbukaan proses penyelenggaraan pelayanan publik. Penilaian terhadap tingkat keterbukaan di sini meliputi seluruh proses pelayanan publik, termasuk di dalamnya adalah persyaratan, biaya dan waktu yang dibutuhkan serta mekanisme atau prosedur pelayanan yang harus dipenuhi. Persyaratan pelayanan harus dipublikasikan secara terbuka dan mudah diketahui oleh para pengguna. Penyelenggara layanan harus berusaha menjelaskan kepada para pengguna mengenai persyaratan yang harus dipenuhi beserta alasan diperlukannya persyaratan itu dalam proses pelayanan.

2. Mengarah pada seberapa mudah peraturan dan prosedur pelayanan dapat dipahami oleh pengguna dan stakeholders yang lain. Maksud dari "dipahami" di sini bukan hanya dalam artiliteral semata tetapi juga makna di balik semua prosedur dan peraturan itu. Penjelasan mengenai 
persyaratan, prosedur, biaya dan waktu yang diperlukan sebagaimana adanya merupakan hal yang sangat penting bagi para pengguna.

3. Kemudahan untuk memperoleh informasi mengenai berbagai aspek penyelenggaraan pelayanan publik. Semakin mudah pengguna memperoleh informasi mengenai berbagai aspek penyelenggaraan pelayanan publik semakin tinggi transparansi.

\section{Manajemen Sumber Daya Manusia}

Menurut Sedarmayanti (2013: 13), manajemen sumber daya manusia adalah kebijakan dan praktik menentukan aspek "manusia" atau sumber daya manusia dalam posisi manajemen, termasuk merekrut, menyaring, melatih, memberi penghargaan dan penilaian. Selanjutnya Sedarmayanti (2013:13), menyatakan tujuan manajemen sumber daya manusia secara umum adalah untuk memastikan bahwa organisasi mampu mencapai keberhasilan melalui orang. Sistem manajemen sumber daya manusia dapat menjadi sumber kapabilitas organisasi yang memungkinkan perusahaan atau organisasi dapat belajar dan mempergunakan kesempatan untuk peluang baru. secara khusus, manajemen sumber daya manusia bertujuan untuk:

1. Memungkinkan organisasi mendapatkan dan mempertahankan karyawan cakap, dapat dipercaya dan memiliki motivasi tinggi, seperti yang diperlukan.

2. Meningkatkan dan memperbaiki kapasitas yang melekat pada manusia kontribusi, kemampuan dan kecakapan mereka.

3. Mengembangkan sistem kerja dengan kinerja tinggi yang meliputi prosedur perekrutan dan seleksi "yang teliti", sistem kompensasi dan insentif yang tergantung pada kinerja, pengembangan manajemen serta aktivitas pelatihan yang terkait "kebutuhan bisnis".
4. Mengembangkan praktik manajemen dengan komitmen tinggi yang menyadari bahwa karyawan adalah pihak terkait dalam organisasi bernilai dan membantu mengembangkan iklim kerja sama dan kepercayaan bersama.

5. Menciptakan iklim, di mana hubungan yang produktif dan harmonis dapat dipertahankan melalui asosiasi antara manajemen dengan karyawan.

6. Mengembangkan lingkungan, di mana kerja sama tim dan fleksibilitas dapat berkembang.

7. Membantu organisasi menyeimbangkan dan mengadaptasikan kebutuhan pihak terkait (pemilik, lembaga atau wakil pemerintah, manajemen, karyawan, pelanggan, pemasok dan masyarakat luas).

8. Memastikan bahwa orang dinilai dan dihargai berdasarkan apa yang mereka lakukan dan mereka capai.

9. Mengelola karyawan yang beragam, memperhitungkan perbedaan individu dan kelompok dalam kebutuhan penempatan, gaya kerja dan aspirasi.

10. Memastikan bahwa kesamaan kesempatan tersedia untuk semua.

11. Mengadopsi pendekatan etis untuk mengelola karyawan yang didasarkan pada perhatian untuk karyawan, keadilan dan transportasi.

12. Mempertahankan dan memperbaiki kesejahteraan fisik dan mental karyawan.

Pengertian lain menurut Wendell French (dalam Gomez 2003: 6) manajemen sumber daya manusia adalah penarikan, seleksi, pengembangan, penggunaan dan pemeliharaan sumber daya manusia oleh organisasi. Pengertian manajemen sumber daya manusia menurut Dale Yoder (dalam Hasibuan 2003: 11) manajemen personalia adalah penyedia kepemimpinan dan pengarahan para karyawan dalam pekerjaan atau hubungan kerja mereka. 
Menurut Dessler (2005: 4) manajemen sumber daya manusia adalah suatu kebijakan dan praktik yang melibatkan seseorang atau aspek sumber daya manusia dari posisi manajemen yang termasuk perekrutan, memilih, melatih, memberikan penghargaan, dan menilai. Berdasarkan definisi di atas dapat ditarik suatu simpulan bahwa manajemen sumber daya manusia adalah suatu fungsi organisasi yang terdiri atas proses dan sistem yang dapat memengaruhi kepegawaian yang efektif dan efisien, sehingga tujuan organisasi dan individual pun dapat dicapai.

Lebih lanjut Russel dan Bernadin dalam Faustino Cardoso Gomes (2003: 4) menyatakan bahwa staffing mencakup kegiatan-kegiatan seperti berikut.

1. Rekrut/mempekerjakan

2. Affirmation action

3. Promosi/pemindahan/separasi

4. Pelayanan-pelayanan outplacement

5. Pengangkatan dan orientasi

6. Metode-metode seleksi pekerja

\section{Rekrutmen}

Tenaga kerja yang baru bagi suatu perusahaan atau organisasi merupakan tantangan bagi manajemen sumber daya manusia, karena perekrutan tenaga kerja merupakan fungsi manajemen sumber daya manusia khususnya perencanaan. Menurut Malayu S. P. Hasibuan (2003: 40) menjelaskan bahwa Penarikan atau perekrutan adalah usaha mencari dan memengaruhi tenaga kerja agar mau melamar lowongan pekerjaan yang ada dalam suatu perusahaan. Pendapat lain dikemukakan oleh Bernadin \& Russel dalam Ambar T. Sulistiyani (2002:134), rekrutmen merupakan proses penemuan dan penarikan para pelamar yang tertarik dan memiliki kualifikasi terhadap lowongan yang dibutuhkan.

Menurut Sheila M. Rioux \& Paul Bernthal dalam Recruitment and Selection Practices mengatakan bahwa:
"Recruitment is the process of identifying and attracting potential candidates from within and outside an organization to begin evaluating them for future employment. Once candidates are identified, an organization can begin the selection process. This includes collecting, measuring, and evaluating information about candidates' qualifications for specified positions. Organizations use these processes to increase the likelihood of hiring individuals who possess the right skills and abilities to be successful at their jobs"

(Perekrutan adalah proses tentang mengidentifikasi dan menarik caloncalon potensial dari dalam dan satu organisasiluar untukmulaimengevaluasi mereka untuk ketenagakerjaan masa depan. Begitu calon calon dikenali, satu organisasi dapat mulai proses pemilihan. Hal ini termasuk pengumpulan, mengukur, dan mengevaluasi informasi tentang kecakapan-kecakapan calon untuk posisi-posisi yang ditetapkan. Organisasi-organisasi gunakan ini semua proses-proses untuk meningkatkan kemungkinan tentang penggunaan merekrut individu yang menguasai keterampilan-keterampilan dan kemampuan-kemampuan yang benar agar berhasil pada pekerjaan mereka).

Menurut Rynes, Bretz, \& Gerhart (1991), dalam Necessity of Effective Communication About Salary and Other Benefits of Entry Level Positions: An Empirical Study, Vol. 3. No. 1 mengatakan bahwa:

"Recruitment is commonly viewed as an element in the socialization process prior to organizational entry. During this stage, employees attempt to attract the type of employee who is most likely to be successful in the organization. This is done, in part, because selection is a two way decision-making process."

(Perekrutan adalah biasanya dipandang sebagai satu unsur di dalam 
proses sosialisasi sebelum masukan organisatoris. Selama langkah dalam tahap ini, usaha para pemberi kerja untuk menarik jenis dari karyawan siapa yang paling mungkin untuk sukses di dalam organisasi. Hal ini dilakukan dalam bagian, karena pemilihan adalah suatu dua proses pengambilan keputusan jalan).

Menurut pendapat Faustino Cardoso Gomes (2003:106) menyebutkan ada tujuh alasan dasar dalam perekrutan, yaitu :

1. Berdirinya organisasi baru.

2. Adanya perluasan kegiatan organisasi.

3. Terciptanya pekerjaan-pekerjaan dan kegiatan-kegiatan baru.

4. Adanya pekerja yang pindah ke organisasi lain.

5. Adanya pekerja yang berhenti, baik dengan hormat maupun tidak dengan hormat sebagai tindakan punitif.

6. Adanya pekerja yang berhenti karena memasuki usia pensiun.

7. Adanya pekerja yang meninggal dunia.

Menurut Siagian (1996:102) rekrutmen adalah proses mencari, menemukan dan menarik para pelamar yang kapabel untuk dipekerjakan dalam dan oleh suatu organisasi. Menurut Sedarmayanti (2013:113) terdapat prosedur dalam proses seleksi, yaitu :

1. Seleksi Persyaratan Administrasi

Pengisian formulir dan persyaratan tertentu sebagai lampiran surat lamaran.

2. Seleksi Pengetahuan Umum

a. Berhubungan dengan ruang lingkup perusahaan/organisasi

b. Berhubungan dengan kenegaraan.

3. Seleksi Psikologi

Untuk mengetahui keadaan dan kesanggupan calon tenaga kerja terhadap kemungkinan dalam memangku jabatan/pekerjaan.

\section{Wawancara}

Untuk mencari dan mendapatkan masukan yang mendalam mengenai motif, harapan dan keinginan pelamar kerja. Harus di usahakan agar pelamar kerja berbicara banyak mengenai dirinya. Pewawancara harus menyiapkan pertanyaan didasarkan pada kualifikasi pendidikan dan pengalaman calon pekerja.

5. Pemberian referensi

6. Uji Kesehatan Fisik

\section{Pegawai Negeri Sipil}

Menurut Widjaja (2006:113) berpendapat bahwa pegawai merupakan tenaga kerja manusia jasmaniah maupun rohaniah (mental dan pikiran) yang senantiasa dibutuhkan dan oleh karena itu menjadi salah satu modal pokok dalam usaha kerja sama untuk mencapai tujuan tertentu (organisasi). Selanjutnya A. W. Widjaja mengatakan bahwa pegawai adalah orang-orang yang dikerjakan dalam suatu badan tertentu, baik di lembaga-lembaga pemerintah maupun dalam badan-badan usaha. Hal ini sesuai dengan pendapat Musanef (1984: 5) yang mengatakan bahwa pegawai adalah orang-orang yang melakukan pekerjaan dengan mendapat imbalan jasa berupa gaji dan tunjangan dari pemerintah atau badan swasta. Selanjutnya Musanef memberikan definisi pegawai sebagai pekerja atau worker adalah mereka yang secara langsung digerakkan oleh seorang manajer untuk bertindak sebagai pelaksana yang akan menyelenggarakan pekerjaan sehingga menghasilkan karya-karya yang diharapkan dalam usaha pencapaian tujuan organisasi yang telah ditetapkan.

Definisi di atas dapat ditarik suatu simpulan bahwa pegawai sebagai tenaga kerja atau yang menyelenggarakan pekerjaan perlu digerakkan sehingga mereka mempunyai keterampilan dan kemampuan dalam bekerja yang pada akhirnya akan 
dapat menghasilkan karya-karya yang bermanfaat untuk tercapainya tujuan organisasi. Karena tanpa kemampuan dan keterampilan pegawai sebagai pelaksana pekerjaan maka alat-alat dalam organisasi tersebut akan merupakan benda mati dan waktu yang dipergunakan akan terbuang dengan percuma sehingga pekerjaan tidak efektif.

Menurut Wikipedia (https:// id.m.wikipedia.org) calon pegawai negeri sipil (CPNS) adalah pegawai yang baru lulus tes seleksi penerimaan CPNS tahap pertama. CPNS belum mengikuti kewajiban untuk memenuhi syarat sebagai PNS dengan gaji 100\%. Mereka digaji dengan persentase sejumlah $80 \%$ berdasarkan SK CPNS yang telah ditentukan dengan berpedoman pada undang-undang yang berlaku di Indonesia. Saat berstatus sebagai CPNS, kompetensi dan kinerja mereka dinilai berdasarkan formasi pada saat mereka dinyatakan lulus seleksi menjadi CPNS. Jika mereka belum memenuhi kriteria penilaian tahap kedua, status calon dapat ditunda dengan ketentuan waktu tertentu. Jika belum memenuhi persyaratan berdasarkan waktu yang ditentukan, mereka dinyatakan gugur atau dibatalkan untuk menjadi PNS.

Berdasarkan ketentuan pada UndangUndang No. 8 Tahun 1974 tentang PokokPokok Kepegawaian, sebagaimana telah diubah dengan Undang-Undang No. 43 Tahun 1999 menyatakan bahwa CPNS yang telah menjalani masa percobaan sekurangkurangnya satu tahun dapat diangkat menjadi PNS setelah memenuhi kewajiban dan persyaratan yang telah ditentukan. Persyaratan yang dimaksud antara lain:

a. Mengikuti Diklat prajabatan, dan memiliki sertifikat yang menyatakan kelulusan Diklat;

b. Surat keterangan sehat jasmani dan rohani dari rumah sakit pemerintah;

c. Pencapaian daftar penilaian pelaksanaan pekerjaan (DP3) dengan predikat nilai minimum yang telah ditentukan.
Undang-Undang No. 43 Tahun 1999 tentang Perubahan atas Undang-Undang No. 8 Tahun 1974 tentang Pokok-Pokok Kepegawaian Pasal 2, menjelaskan Pegawai Negeri Sipil terdiri dari:

1. Pegawai Negeri Sipil Pusat.

a. Yang bekerja sama pada departemen, lembaga pemerintah nondepartemen, kesekretariatan, lembaga tertinggi/tinggi negara, instansi vertikal di daerah-daerah dan kepaniteraan pengadilan.

b. Yang bekerja pada perusahaan jawatan misalnya perusahaan jawatan kereta api, pegadaian dan lain-lain.

c. Yang diperbantukan atau dipekerjakan pada pemerintah provinsi dan pemerintah kabupaten/kota.

d. Yang berdasarkan suatu peraturan perundang-undangan dan diperbantukan atau dipekerjakan pada badan lain seperti perusahaan umum, yayasan dan lainnya.

e. Yang menyelenggarakan tugas negara lainnya, misalnya hakim pada pengadilan negeri/pengadilan tinggi dan lain-lain.

2. Pegawai Negeri Sipil Daerah.

Pegawai negeri sipil daerah diangkat dan bekerja pada pemerintahan daerah otonom baik pada pemerintah provinsi dan pemerintah kabupaten/kota.

3. PegawaiNegeriSipil Lainyang ditetapkan dengan peraturan pemerintah.

Masih dimungkinkan adanya PNS lainnya yang akan ditetapkan dengan peraturan pemerintah, misalnya kepala-kepala kelurahan dan pegawai negeri di kantor sesuai dengan UndangUndang No. 43 Tahun 1999 tentang Perubahan Atas Undang-Undang No. 8 Tahun 1974 tentang Pokok-Pokok Kepegawaian. 


\section{Tenaga Honorer}

Berdasarkan Peraturan Pemerintah No. 56 Tahun 2012 tentang Perubahan Kedua atas Peraturan Pemerintah No. 48 Tahun 2005 tentang Pengangkatan Tenaga Honorer menjadi Calon Pegawai Negeri Sipil, tenaga honorer adalah seseorangyang diangkat oleh pejabat pembina kepegawaian atau pejabat lain dalam pemerintah untuk melaksanakan tugas tertentu pada instansi pemerintah atau yang penghasilannya menjadi beban anggaran pendapatan dan belanja negara (APBN) atau anggaran pendapatan dan belanja daerah (APBD). Pejabat pembina kepegawaian adalah pejabat yang berwenang mengangkat, memindahkan, dan memberikan PNS di lingkungannya sesuai dengan peraturan perundang-undangan

Tenaga honorer terbagi menjadi dua kategori sesuai dengan Peraturan Pemerintah 56 Tahun 2012 tentang Perubahan Kedua Atas Peraturan Pemerintah No. 48 Tahun 2005 tentang Pengangkatan Tenaga Honorer menjadi Calon Pegawai Negeri Sipil, yaitu sebagai berikut.

\section{1) Kategori 1 (K1)}

Tenaga honorer yang penghasilannya dibiayai dari APBN atau APBD dengan kriteria diangkat oleh pejabat yang berwenang bekerja di instansi pemerintah, masa kerja paling sedikit 1 (satu) tahun pada 31 Desember 2005 dan sampai saat ini masih bekerja secara terus menerus; berusia paling rendah 19 (sembilan belas) tahun dan tidak boleh lebih dari 46 (empat puluh enam) tahun pada 1 Januari 2006.

2) Kategori 2 (K2)

Tenaga honorer yang penghasilannya dibiayai bukan dari APBN atau APBD dengan kriteria, diangkat oleh pejabat yang berwenang, bekerja di instansi pemerintah, masa kerja paling sedikit 1 (satu) tahun pada 31 Desember 2005 dan sampai saat ini masih bekerja secara terus menerus, berusia paling rendah 19 (sembilan belas) tahun dan tidak boleh lebih dari 46 (empat puluh enam) tahun pada 1 Januari 2006.

\section{Kerangka Pemikiran}

Hal pokok yang menjadi perhatian utama pada penelitian ini, yaitu Transparansi Rekrutmen CPNS dari tenaga honorer kategori II dan umum dengan latar belakang pendidikan dan umu sesuai latar belakang pendidikan pada Badan Kepegawaian Pendidikan dan Pelatihan (BKPP) Kabupaten Sumedang Provinsi Jawa Barat. Konsep transparansi yang dijadikan rujukan dalam kerangka pikir ini diadopsi dari pendapat Agus Dwiyanto. Indikator transparansi yang dimaksud adalah:

1) Keterbukaan proses penyelenggaraan

a. Persyaratan dalam pelaksanaan penerimaan CPNS dari tenaga honorer K2 sudah disampaikan oleh BKPP;

b. Tidak ada biaya yang harus dikeluarkan oleh para peserta seleksi, semua biaya ditanggung oleh APBD

c. Setiap tahapan seleksi selalu disertai dengan lamanya waktu pelaksanaan yang ditempelkan di papan pengumuman kantor BKPP.

d. Adanya penyampaian tahapantahapan yang harus dilakukan oleh peserta seleksi dari pendaftaran sampai dengan pengumuman lulus dan verifikasi berkas kembali, terakhir pemberkasan dan penetapan NIP.

2) Kemudahan dalam memahami prosedur

a. Persyaratan yang diberikan sudah cukup jelas sesuai dengan Peraturan Kepala BKN No. 9 Tahun 2012

b. Semua biaya ditanggung oleh APBD

c. Penjelasan lamanya waktu sudah 
diberikan, dan apabila ada perubahan jadwal akan diinformasikan lebih lanjut.

d. Prosedur pelaksanaan seleksi sudah jelas, tahapantahapan yang harus di laksanakan oleh peserta seleksi.

e. Panitia penyelenggara pelaksanaan rekrutmen telah disusun berdasarkan Surat Keputusan Bupati Sumedang, dan diberikan pengetahuan tentang pelaksanaan penerimaan CPNS dari tenaga honorer K2.

3) Kemudahan dalam mengakses informasi

Penyebaran informasi penerimaan CPNS dari tenaga honorer K2 sudah disebarluaskan kepada seluruh tenaga honorer K2 baik melalui media ataupun secara langsung.

Peserta seleksi dapat melihat hasil pengumuman kelulusan CPNS dari tenaga honorer K2 secara langsung melalui website MenPAN, sebelum hasil tersebut dikirim ke BKPP dan selanjutnya akan diinformasikan kepada tenaga honorer yang dinyatakan lulus. sesuai dengan Peraturan Bupati Sumedang No. 25 Tahun 2017 tentang Uraian Tugas Jabatan Struktural pada Badan Kepegawaian dan Pengembangan Sumber Daya Manusia dan Peraturan Kepala BKN No. 9 Tahun 2017

Dari uraian tersebut di atas tentang indikator transparansi, selanjutnya dapat digambarkan dalam kerangka pikir sebagai berikut.

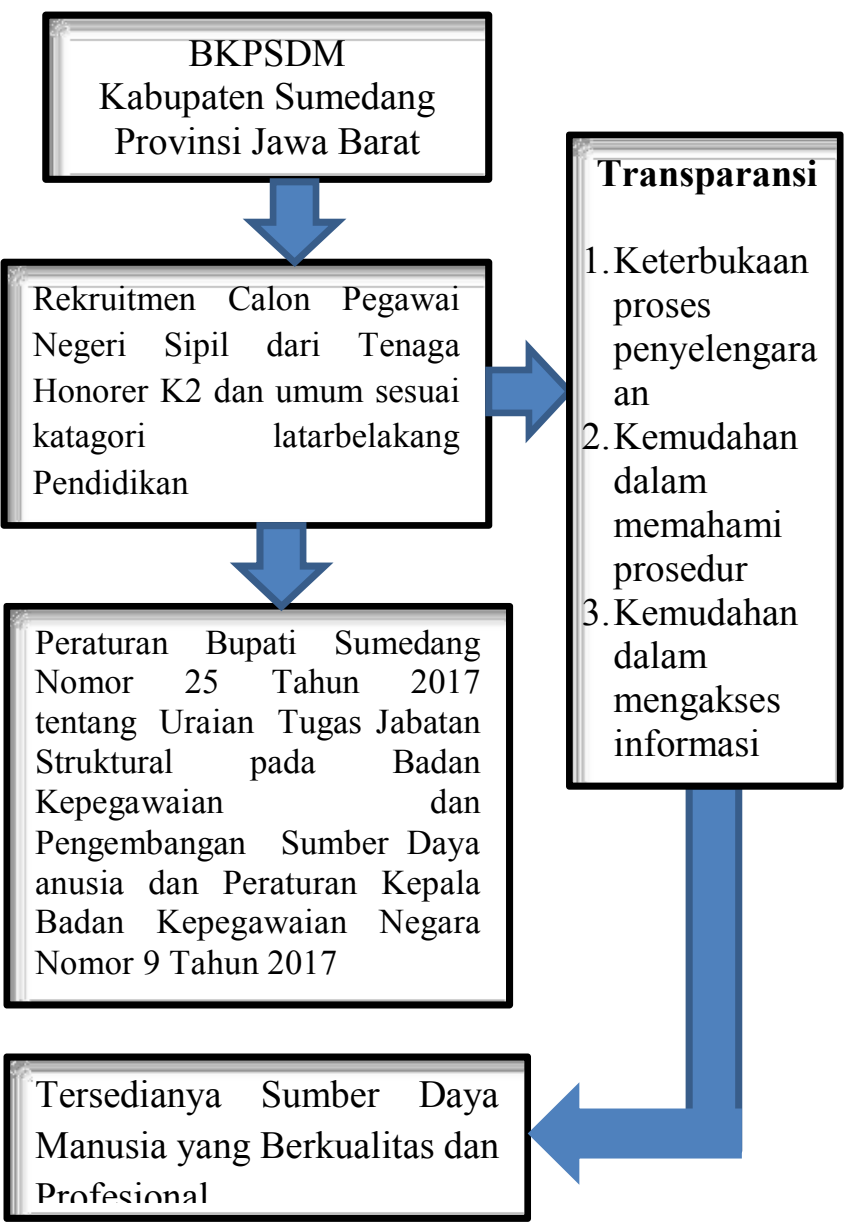

Gambar 1

Kerangka Pikir

(Sumber: Olahan peneliti lingkup penelitian)

\section{METODE PENELITIAN}

Metode penelitian yang digunakan merupakan penelitian deskriptif dengan pendekatan kualitatif, Metode penelitian kualitatif digunakan karena peneliti bermaksud memperoleh gambaran yang mendalam mengenai transparansi dalam proses rekrutmen CPNS dari tenaga honorer kategori II dan umum dengan latar belakang pendidikan pada BKPSDM Kabupaten Sumedang Provinsi Jawa Barat

Dalam penelitian ini, digunakan konsep transparansi menurut pendapat Agus Dwiyanto. Indikator transparansi yang dimaksud adalah sebagai berikut. 
(a) Keterbukaan proses penyelenggaraan, artinya persyaratan, biaya, waktu dan prosedur yang ditempuh harus dipublikasikansecaraterbukadanmudah diketahui oleh yang membutuhkan, serta berusaha menjelaskan alasannya.

(b) Kemudahan dalam memahami prosedur. Indikator ini berkaitan dengan bahwa sebuah peraturan dan prosedur rekrutmen harus cukup jelas dimengerti oleh pengguna jasa. Petugas penyelenggara harus memiliki kemampuan dan tersedianya mekanisme yang memungkinkan pengguna jasa dapat memahami dengan jelas mulai dari persyaratan, biaya, waktu dan prosedur yang harus dilakukan.

(c) Kemudahan dalam mengakses informasi. Indikator ini mensyaratkan bahwa dalam penyelenggaraan rekrutmen, maka petugas penyelenggara dituntut untuk memudahkan proses penyebaran informasi kepada pengguna jasa dalam setiap aspek penyelenggaraannya. Informasi tersebut bebas didapat dan siap tersedia.

\section{Informan Penelitian}

Dalam penelitian ini, teknik penentuan informan yang digunakan adalah teknik purposive. Teknik purposive, yaitu metode atau teknik penentuan informan yang disesuaikan dengan tujuan penelitian dan hanya mengambil beberapa unit informan saja yang diambil secara langsung dan dianggap mewakili dan mengetahui permasalahan. Dengan kata lain bahwa informan yang dipilih dianggap mengetahui dan memahami permasalahan.

informan yang akan diwawancarai adalah (1) Pemerintah dalam hal ini adalah pihak yang menyelenggarakan rekrutmen CPNS yakni BKPSDM Kabupaten Sumedang Provinsi Jawa Barat. Adapun jumlah informan yang dipilih sebagai representasi dari pemerintah adalah sebanyak 3 orang, yaitu
Kepala BKPSDM, Sekretaris BKPSDM dan Kepala Bidang Pengadaan dan Kepangkatan Pegawai pada BKPSDM Kabupaten Sumedang Provinsi Jawa Barat. (2) Peserta seleksi dalam hal ini adalah mantan pelamar CPNS dari tenaga honorer yang pernah terlibat langsung dalam pelaksanaan rekrutmen pegawai negeri sipil. Untuk peserta seleksi itu sendiri informannya terbagi 2 kategori, yaitu peserta yang mengikuti seleksi dan peserta seleksi yang dinyatakan lulus menjadi calon pegawai negeri sipil. Adapun informan yang dipilih sebagai representasi dari masyarakat adalah sebanyak 5 orang, yaitu 3 orang dari peserta yang mengikuti seleksi dan 2 orang dari peserta seleksi yang dinyatakan lulus calon pegawai negeri sipil.

\section{Teknik Pengumpulan dan Analisis Data}

Teknik dalam pengumpulan data digunakan metode observasi, dokumentasi wawancara dan data sekunder, maka instrumennya adalah pedoman wawancara sehingga Penulis melakukan wawancara serta pencatatan terhadap data yang diperlukan terkait Transparansi Rekrutmen Calon Pegawai Negeri Sipil pada BKPSDM Kabupaten Sumedang Provinsi Jawa Barat.

Analisis data yang dilakukan pada penelitian ini menggunakan langkahlangkah yang dikemukakan oleh Sugiyono (2013), yaitu data reduction (data reduksi), data displai (penyajian data) dan Conclusion Drawing/Verification. Untuk memvalidasi ataupun keabsahan data digunakan metode triangulasi. Pemeriksaan dan pengecekan dilakukan peneliti pada penelitian ini adalah melalui sumber lain, yaitu dengan cara membandingkan data hasil pengamatan wawancara dengan teori yang dipakai.

\section{HASIL DAN PEMBAHASAN}

\section{Keterbukaan Proses Penyelenggaraan}

Dalam rekrutmen CPNS dari tenaga honorer 2013, proses penerimaan berkas 
pelamar CPNS dilakukan di Kantor BKPSDM Kabupaten Sumedang dengan dilayani oleh Panitia Seleksi Penerimaan CPNS daerah Kabupaten Sumedang yang dibentuk berdasarkan Surat Keputusan Bupati Sumedang No. 800.50/KEP.301-BKD/2013. Sebelum melaksanakan seleksi administrasi untuk penerimaan CPNS dari tenaga honorer, panitia yang dibentuk tersebut telah menyampaikan hal-hal apa saja yang harus dipenuhi.

Dalam pelaksanaan seleksi terdapat persyaratan-persyaratan yang harus dipenuhi untuk mengikuti seleksi tes penerimaan CPNS. Selanjutnya ketika persyaratan tersebut telah terpenuhi maka pelamar dari tenaga honorer dapat mengikuti tes seleksi administrasi untuk proses penerimaan CPNS, dalam proses tersebut panitia akan melakukan pendataan. Seleksi administrasi merupakan tahap yang akan menentukan apakah tenaga honorer dapat mengikuti tahap selanjutnya, yaitu tahap seleksi akademik atau tidak dapat diterima menjadi CPNS di lingkungan Kabupaten Sumedang dengan dinyatakan sebagai pelamar yang tidak memenuhi syarat (TMS).

Dalam pelaksanaan prosedur-prosedur ataupun tahapan dalam penerimaan CPNS dari tenaga honorer kategori II dan umum dengan latar belakang pendidikan, disebutkan juga tentang waktu dan biaya yang harus diketahui oleh seluruh tenaga honorer. Setiap pelaksanaan tahapan-tahapan seleksi selalu diikuti dengan waktu kegiatan, ini dilakukan agar peserta seleksi mengetahui dan dapat mempersiapkan diri dalam pelaksanaan seleksi nantinya. Selanjutnya untuk biaya pelaksanaan seleksi penerimaan CPNS dari tenaga honorer kategori II dan umum dengan latar belakang pendidikan ini tidak membebankan kepada peserta seleksi, tapi pembiayaan semua dikeluarkan oleh APBD. Selain itu pada pelaksanaan seleksi dilakukan dengan pengawasan yang baik, di mana adanya panitia dari BKPSDM, panitia pusat dan media.
Keterbukaan proses rekrutmen CPNS dari tenaga honorer kategori II dan umum dengan latar belakang pendidikan sudah dilaksanakan dengan baik oleh pihak penyelenggara. Hal ini tercermin dari terbukanya persyaratan yang harus dimiliki oleh para calon seleksi, waktu lamanya kegiatan yang harus ditempuh, dan tidak adanya biaya yang harus dikeluarkan oleh calon pelamar karena semua pembiayaan dibebankan oleh APBD, serta prosedur atau tahapan yang harus dilakukan oleh para calon pelamar. Selain itu dalam tahapan pelaksanaan seleksi akademik, ada beberapa unsur lembaga yang ikut mengawasi pelaksanaan. di mana ada dari Panselnas Pusat dan Daerah, bahkan ada juga media yang ikut mengawasi, ini dilakukan agar pelaksanaan seleksi dapat dilakukan secara terbuka.

\section{Kemudahan dalam Memahami Prosedur}

Panitia penyelenggara penerimaan CPNS dari tenaga honorer sudah diberikan materi tentang kegiatan penerimaan, sehingga dapat diartikan bahwa mereka telah memiliki kemampuan dan pemahaman tentang rekrutmen CPNS dari tenaga honorer, walaupun masih banyak kekurangan yang dimiliki. Penerimaan CPNS dari tenaga honorer kategori II dan umum dengan latar belakang pendidikan yang dilaksanakan sudah diberikan penjelasan yang baik dari panitia seleksi kepada para calon pelamar, sehingga para tenaga honorer yang ingin mengikuti seleksi dapat memahami dengan baik hal-hal yang harus dilakukan oleh pelamar sebelum mengikuti kegiatan seleksi. Selanjutnya diberikan kejelasan tentang waktu yang harus ditanggung oleh calon pelamar. Dan untuk biaya pada saat seleksi, semua dibebani oleh pemerintah Kabupaten Sumedang.

Pelaksanaan penerimaan CPNS dari tenaga honorer kategori II dan umum dengan latar belakang pendidikan sudah diberikan 
penjelasan tentang prosedur ataupun tahapan-tahapan yang harus dilakukan oleh para calon tenaga honorer yang mengikuti seleksi kategori II. Semua prosedur-prosedur penerimaan CPNS dari tenaga honorer kategori II dan umum dengan latar belakang pendidikan berpedoman pada Peraturan Kepala Badan Kepegawaian Negara No. 9 Tahun 2012 tentang Pedoman Pelaksanaan Pengadaan Calon Pegawai Negeri Sipil.

Dari berbagai penjelasan di atas, dapat disimpulkan bahwa pemahaman BKPSDM Kabupaten Sumedang selaku penyelenggara rekrutmen CPNS dari tenaga honorer kategori II dan umum dengan latar belakang pendidikan sudah dapat memahami karena mereka telah diberikan suatu bahan ataupun briefing tentang proses rekrutmen CPNS dari tenaga honorer kategori II dan umum dengan latar belakang pendidikan. Dan juga penjelasan-penjelasan yang diberikan kepada calon pelamar yang berhubungan tentang rekrutmen CPNS sudah jelas dan dapat dipahami oleh para calon pelamar. Baik itu dari persyaratan, waktu, biaya dan prosedur yang harus diikuti, sehingga telah memenuhi salah satu indikator transparansi yang dikemukakan oleh Agus Dwiyanto.

\section{Kemudahan dalam Mengakses Informasi}

Kemudahan dalam mengakses informasi ini erat kaitannya dengan pengumuman yang disampaikan oleh penyelenggara kepada para pelamar. Penyebaran informasi pengumuman penerimaan CPNS dari tenaga honorer dari kategori II dilakukan melalui website, media cetak dan elektronik, dan juga disampaikan langsung kepada Pimpinan OPD untuk diinformasikan langsung kepada para tenaga honorer. Selanjutnya dilakukan pendataan terhadap tenaga honorer yang akan mengikuti seleksi penerimaan.

Selanjutnyatahapanfinalpadarekrutmen CPNS dari tenaga honorer kategori II dan umum dengan latar belakang pendidikan tahun 2013 adalah pengumuman kelulusan. Berdasarkan hasil pemeriksaan LJK yang dilakukan oleh panitia seleksi nasional di Jakarta, maka ditentukan nama-nama peserta yang dinyatakan lulus ujian penerimaan CPNS dari tenaga honorer kategori II dan umum dengan latar belakang pendidikan. Pengumuman nama-nama tenaga honorer K II yang lulus CPNS 2013 akan diumumkan dalam laman website www.menpan. go.id. Website tersebut adalah merupakan website resmi Kementerian Pendayagunaan Aparatur Negara dan Reformasi Birokrasi (PAN-RB) yang akan memperlihatkan nama peserta tes CPNS honorer kategori II yang lulus dan menjadi CPNS pada 2013-2014. Dan selanjutnya pengumuman kelulusan tersebut akan diinformasikan juga kepada BKPSDM Kabupaten Sumedang untuk disampaikan kepada tenaga honorer yang lulus melalui masing-masing instansi tempat tenaga honorer itu bekerja.

Di dalam pengumuman tersebut jumlah tenaga honorer kategori II dan umum dengan latar belakang pendidikan Kabupaten Sumedang yang dinyatakan lulus berjumlah 970 orang. Hasil pengumuman tersebut diumumkan secara luas kepada masyarakat melalui media cetak dan internet, selain itu pengumuman juga disampaikan kepada pimpinan OPD untuk diinformasikan kepada tenaga honorer yang lulus secara langsung.

Dari hasil penjelasan di atas dapat dijelaskan bahwa pengumuman hasil seleksi penerimaan CPNS Kabupaten Sumedang dirasakan sudah cukup untuk menyebarluaskan hasil seleksi tersebut. di mana nama-nama peserta yang lulus dapat dilihat melalui internet website MenPAN, dan juga ada ditempelkan di papan pengumuman kantor BKPSDM Kabupaten Sumedang, selain itu disampaikan juga kepada tenaga honorer melalui pimpinan OPD masing-masing

Secara umum dapat disimpulkan bahwa pelaksanaan proses rekrutmen PNS yang dilaksanakan oleh Badan Kepegawaian 
Pengembangan Sumber Daya Manusia Kabupaten Sumedang sudah transparan. Hal tersebut dapat dilihat dari hal-hal berikut ini.

(a) Keterbukaannya proses pelaksanaan, dari persyaratan, waktu, biaya dan tahapan atau prosedur seleksi, serta adanya unsur lain yang mengawasi baik dari panitia pusat dan daerah, dan bahkan media diikutkan dalam pengawasan rekrutmen.

(b) Kemudahan dalam kejelasan tentang proses seleksi penerimaan CPNS kepada tenaga honorer. serta adanya kemampuan dari panitia penyelenggara terhadap proses penerimaan CPNS.

(c) Kemudahan untuk memperoleh informasi dalam proses rekrutmen juga sudah sepenuhnya terlaksana. di mana informasi penerimaan CPNS dari tenaga honorer sudah disebarluaskan kepada tenaga honorer yang berada di Kabupaten Sumedang, baik melalui media maupun dilakukan secara langsung. Sama halnya dengan informasi pengumuman kelulusan, penyebaran informasi tersebut telah dilakukan dengan mudah, sehingga tenaga honorer dapat mengetahui dan mempersiapkan persyaratan selanjutnya.

Faktor-faktor yang menghambat transparansi rekrutmen CPNS dari tenaga honorer kategori II dan umum dengan latar belakang pendidikan dan upaya yang diberikan adalah sebagai berikut.

\section{- Pengumuman oleh Panselnas}

Proses pengumuman yang dilakukan oleh Panitia Seleksi Nasional (PANSELNAS) tersebut telah dilakukan dengan baik karena informasi langsung dapat diakses oleh seluruh pelamar dari tenaga honorer. Walaupun demikian, di dalam pengumuman tersebut peserta tidak dapat mengetahui secara jelas bagaimana proses penentuan rangking dan nilai hasil akhir para pelamar. Keadaan tersebut mengundang pertanyaan dari peserta seleksi yang tidak lulus. Apakah hasil yang diumumkan tersebut betul-betul sesuai dengan keadaan atau hasil manipulasi.

Penyampaian informasi pengumuman kelulusan CPNS dari tenaga honorer kategori II dan umum dengan latar belakang pendidikan tahun 2013 tidak mencantumkan skor akhir, hanya mencantumkan nama dan nomor peserta seleksi yang lulus. Hal tersebut membuat tidak adanya kepuasan dari tenaga honorer yang tidak lulus, karena mereka tidak mengetahui hasil skor akhirnya. Akibatnya dapat menimbulkan persepsi negatif di kalangan tenaga honorer khususnya bagi tenaga honorer yang dinyatakan tidak lulus.

Oleh sebab itu untuk mengatasi permasalahan ini, upaya yang dilakukan adalah dengan cara mengusulkan kepada pemerintah pusat untuk merevisi kembali peraturan tentang tenaga honorer, khususnya pada bagian penyampaian informasi pengumuman kelulusan. Agar dapat disertai dengan pemberian Nilai Skor Akhir dan Passing grade agar tidak terjadi konflik di daerah dan tenaga honorer dapat mengetahui dengan jelas, sehingga dapat menghilangkan persepsi negatif yang mereka pikirkan.

\section{- Pendidikan Tenaga Honorer}

Pendidikan yang dimiliki seorang tenaga honorer berbeda-beda, ada yang merupakan lulusan SD, SMP, SMA dan perguruan tinggi. Akibatnya kemampuan tentang berbagai hal juga berbeda. Dalam proses penyelenggaraan penerimaan CPNS dari tenaga honorer masih terhambat di bagian pendidikan tenaga honorer itu sendiri, di mana tidak semua tenaga honorer mengetahui tata cara penggunaan komputer. yang di mana menyebabkan mereka akan sulit dan menghambat untuk melaksanakan tes akademik dengan maksimal, sehingga mereka harus gagal menjadi seorang calon pegawai negeri sipil. 
Untuk mengatasi permasalahan dari pendidikan tersebut. Bisa diusulkan kepada pemerintah pusat tentang mekanisme penyelenggaraan rekrutmen CPNS dari tenaga honorer yang bisa dipahami bagi tenaga honorer yang berpendidikan di bawah rata-rata. Ataupun kebijakan tersendiri yang mereka bisa dapatkan dikarenakan adanya unsur pengabdian kepada pemerintah yang telah lama mereka kerjakan.

\section{- Partisipasi Masyarakat}

Pemerintah Kabupaten Sumedang merupakan panitia pelaksana dalam kegiatan rekrutmen calon pegawai negeri sipil, selain itu dibutuhkan suatu partisipasi dari masyarakat itu sendiri untuk membantu terciptanya pelaksanaan rekrutmen yang baik dan menciptakan suatu transparansi. Tapi dalam pelaksanaan rekrutmen ini, partisipasi yang diberikan oleh masyarakat masih kurang. di mana pada saat pelaksanaan uji publik tenaga honorer yang akan mengikuti seleksi hanya memperhatikan diri mereka sendiri tanpa memperhatikan orang lain. Tetapi ketika hasil telah dikeluarkan mereka yang dinyatakan tidak lulus, baru mencari-cari tenaga honorer yang tidak memenuhi syarat. Dan kemudian melaporkan bahwa telah terjadi kecurangan dalam proses penyelenggaraannya.

Untuk menciptakan partisipasi masyarakat mereka harus diberikan pemahaman dan kesadaran tentang hidup bersama bukan hidup masing-masing. Mereka harus selalu diberikan tugas bergotong-royong agar menciptakan rasa kebersamaan. Selain itu, unsur pimpinan dan panitia penyelenggara harus melakukan mekanisme penyelenggaraan secara maksimal dan Pendataan tenaga honorer harus betul-betul diperhatikan. Dan harus terus melibatkan tenaga honorer yang lain untuk memperhatikan proses penyelenggaraan rekrutmen CPNS dari tenaga honorer kategori II dan umum dengan latar belakang pendidikan ini.

\section{SIMPULAN}

Secara umum dapat disimpulkan bahwa pelaksanaan proses rekrutmen PNS yang dilaksanakan oleh Badan Kepegawaian Pengembangan Sumber Daya Manusia Kabupaten Sumedang sudah transparan. Hal tersebut dapat dilihat dari (a) Keterbukaannya proses pelaksanaan, dari persyaratan, waktu, biaya dan tahapan atau prosedur seleksi, serta adanya unsur lain yang mengawasi baik dari panitia pusat dan daerah, dan bahkan media diikutkan dalam pengawasan rekrutmen. (b) Kemudahan dalam kejelasan tentang proses seleksi penerimaan CPNS kepada tenaga honorer. serta adanya kemampuan dari panitia penyelenggara terhadap proses penerimaan CPNS. (c) Kemudahan untuk memperoleh informasi dalam proses rekrutmen juga sudah sepenuhnya terlaksana. di mana informasi penerimaan CPNS dari tenaga honorer sudah disebarkan luaskan kepada tenaga honorer yang berada di Kabupaten Sumedang, baik melalui media maupun dilakukan secara langsung. Sama halnya dengan informasi pengumuman kelulusan, penyebaran informasi tersebut telah dilakukan dengan mudah, sehingga tenaga honorer dapat mengetahui dan mempersiapkan persyaratan selanjutnya.

Faktor-faktor yang menghambat transparansi rekrutmen CPNS, yaitu (a) Pengumuman yang diberikan oleh Panitia Seleksi Nasional belum disampaikan dengan jelas dan mendetail. (b) Pendidikan dari tenaga honorer yang berbeda-beda, di mana tidak semua tenaga honorer mengetahui tata cara penggunaan komputer. (c) Kurangnya partisipasi masyarakat dalam rekrutmen CPNS dari tenaga honorer kategori II.

Upaya yang dilakukan untuk mengatasi faktor-faktor yang menghambat transparansi, sesuai antara lain: (a) memberikan usulan kepada panitia pusat untuk merevisi kembali peraturan tentang tenaga honorer, khususnya pada bagian 
penyampaian informasi pengumuman kelulusan. Agar dapat disertai dengan pemberian NilaiSkor Akhir dan Passing grade. (b) memberikan usulan kepada pemerintah pusat tentang mekanisme penyelenggaraan rekrutmen CPNS dari tenaga honorer yang bisa dipahami bagi tenaga honorer yang berpendidikan di bawah rata-rata. Ataupun kebijakan tersendiri yang mereka bisa dapatkan dikarenakan adanya unsur pengabdian kepada pemerintah yang telah lama mereka kerjakan. (c) tenaga honorer harus selalu diberikan tugas bergotongroyong agar menciptakan rasa kebersamaan. Selain itu, unsur pimpinan dan panitia penyelenggara harus melakukan mekanisme penyelenggaraan secara maksimal lagi dan Pendataan tenaga honorer harus betul-betul diperhatikan.

\section{DAFTAR PUSTAKA}

Arikunto, Suharsimi. 2013. Prosedur Penelitian: Suatu Pendekatan Praktik. Jakarta: PT Rineka Cipta

Ambar T. Sulistiyani. 2002. Manajemen Sumber Daya Manusia. Jakarta: Graha Ilmu.

A. W. Widjaja. 2006. Administrasi Kepegawaian. Jakarta: Rajawali

Basrowi \& Suandi, 2008, Memahami Penelitian Kualitatif, jakarta: PT Rineka Cipta.

Dahar, R. 1996. Teori-Teori Belajar. Jakarta: Erlangga

Dessler, Gary. 2005. Manajemen Sumber Daya Manusia. Alih bahasa: Eli Tanya. Penyunting Bahasa: Budi Supriyanto. Jakarta: Indeks.

Dwiyanto, Agus, 2008, Mewujudkan Good Governance Melalui Pelayanan Publik, Yogyakarta: Gama Press.

Gomes, Faustino Cardoso, 2003, Manajemen Sumber Daya Manusia. Yogyakarta: Andi offset.

Hasibuan, S, P, Malayu. 2003. Manajemen Dasar, Pengertian dan Masalah. Jakarta: Bumi Aksara.
2003. Manajemen Sumber Daya Manusia. Jakarta: Bumi Aksara.

Moleong, Lexy J. 2005. Metodologi Penelitian Kualitatif. Bandung: remaja Rosda Karya.

Musanef. 1984. Manajemen Kepegawaian di Indonesia. Jakarta: Gunung Agung.

Nasution, S. 2008. Asas-Asas Kurikulum. Jakarta: Bumi Aksara

Nazir, Moh. 2013. Metode Penelitian. Jakarta: Ghalia Indonesia.

Ndraha, Taliziduhu. 2005. Kybernology Sebuah Rekonstruksi Ilmu Pemerintahan. Jakarta: PT. Rineka Cipta

Patilima, Hamid. 2011. Metode Penelitian Kualitatif. Bandung: Alfabeta.

Pieris, John dan Nizam Jim Wiryawan. 2008. Etika Bisnis \& Good Corporate Governance, edisi kedua. Jakarta: Pelangi Cendekia.

Riduwan. 2004. Metode dan Teknik Menyusun Tesis. Bandung: Alfabeta.

Sedarmayanti, 2013, Manajemen Sumber Daya Manusia, Reformasi Birokrasi, dan Manajemen Pegawai Negeri Sipil, Bandung: PT Refika Aditama.

Soedjadi, 2000, Pedoman Penulisan dan Ujian Skripsi. Surabaya: Unesa Universitas Press.

Sondang P. Siagian. 1996. Manajemen Sumber Daya Manusia. Jakarta: Bumi Aksara.

Simanjuntak, Payaman, J. 2001. Ekonomi Sumber Daya Manusia. Jakarta: Fakultas Ekonomi Universitas Indonesia.

Sugiyono. 2013. Metode Penelitian Pendidikan (Pendekatan Kuantitatif, Kualitatif, dan $R \& D$. Bandung: Alfabeta.

Widodo, Joko. 2001. Good Governance: Telaah dari Dimensi Akuntabilitas dan Kontrol Birokrasi pada Era Desentralisasi dan Otonomi Daerah. Surabaya: Insan Cendekia.

\section{Peraturan Perundang-Undangan}

Undang-Undang No. 43 Tahun 1999 tentang Perubahan Atas Undang-Undang No. 8 Tahun 1974 tentang Pokok-Pokok Kepegawaian. 
Undang-Undang No. 23 Tahun 2014 tentang Pemerintahan Daerah.

Peraturan Pemerintah No. 97 Tahun 2000 tentang Formasi Pegawai Negeri Sipil.

Peraturan Pemerintah No. 100 Tahun 2000 tentang Pengangkatan Pegawai Negeri Sipil Dalam Jabatan Struktural.

Peraturan Pemerintah No. 101 Tahun 2000 tentang Pendidikan dan Pelatihan Jabatan Pegawai Negeri Sipil.

Peraturan Pemerintah No. 11 Tahun 2002 tentang Perubahan Atas Peraturan Pemerintah No. 98 Tahun 2000 tentang Pengadaan Pegawai Negeri Sipil.

Peraturan Pemerintah No. 54 Tahun 2003 tentang Perubahan Atas Peraturan Pemerintah No. 97 Tahun 2000 tentang Formasi Pegawai Negeri Sipil.

Peraturan Pemerintah No. 9 Tahun 2003 tentang Wewenang Pengangkatan, Pemindahan dan Pemberhentian Pegawai Negeri Sipil.

Peraturan Pemerintah No. 56 Tahun 2012 tentang Perubahan Kedua Atas Peraturan Pemerintah No. 48 Tahun 2005 tentang Pengangkatan Tenaga Honorer Menjadi Calon Pegawai Negeri Sipil.

Peraturan Kepala Badan Kepegawaian Negara No. 9 Tahun 2012 tentang Pedoman Pelaksanaan Pengadaan Calon Pegawai Negeri Sipil.

Keputusan BupatiSumedangNo.800.05/KEP.301BKD/2013 tentang Pembentukan Panitia Seleksi Penerimaan Calon Pegawai Negeri Sipil Daerah Kabupaten Sumedang dari tenaga honorer kategori II dan umum dengan latar belakang pendidikan Formasi Tahun 2013

\section{Sumber Lain}

Alfianingsih, Firman Wigati, Tesis 2007, Transparansi Rekrutmen Pegawai Negeri Sipil pada era PP No. 6 Tahun 1976 dan PP No. 98 Tahun 2000 (Studi kasus di Kabupaten Pati), Universitas Gadjah Mada.

Buku Pedoman Penguatan Pengaman Program Pembangunan Daerah, Badan
Perencanaan Pembangunan Nasional dan Departemen Dalam Negeri, 2002:18)

Deputi Bidang SDM Aparatur Kementerian Pendayagunaan Aparatur Negara dan Reformasi Birokrasi. Kebijakan Seleksi CPNS tahun 2013 dari Formasi Umum dan Seleksi tenaga honorer kategori II dan umum dengan latar belakang pendidikan (Power Point).

Loina Laolo Krina P, Indikator dan alat ukur prinsip akuntabilitas, transparansi dan partisipasi. Melalui http:/Bappenas.go.id

Rynes, Bretz \& Gerhart. 1991, dalam Necessity of Effective Communication About Salary and Other Benefits of Entry Level Positions: An Empirical Study, Vol. 3. No.1 (http://www. Daffodilvarsity. Edu. Bd/ library/opac/b\&e/v3n1j8/5=Iftekhar\% 20Amin\%20Chowdhury. Pdf)

Sheila M. Rioux, Ph. D., and Paul Bernthal, Ph. D. Dalam Recruitment and Selection Practices (http://www.scribd.com/ doc/23658534/The-Role-of-Recruitment-and-Selection)

Wahyu, Widayat, Tesis 2008, Pengaruh Politisi terhadap Proses Rekrutmen PNS di Jawa Barat (Studi kasus di Biro Organisasi dan Kepegawaian Setda Jawa Barat), Universitas Gadjah Mada.

Wikipedia(http://id.m.wikipedia.org/wiki/ Calon_Pegawai_Negeri_Sipil)

Zebua, Elman Sama'aro, Tesis 2010, Rekrutmen Pegawai Negeri Sipil (Studi di Pemerintah Kota Yogyakarta), Universitas Gadjah Mada. 